Maurice A. Deane School of Law at Hofstra University

Scholarly Commons at Hofstra Law

Hofstra Law Faculty Scholarship

2020

\title{
Toward a Theory of Intercountry Human Rights: Global Capitalism and the Rise and Fall of Intercountry Adoption
}

Barbara Stark

Maurice A. Deane School of Law at Hofstra University

Follow this and additional works at: https://scholarlycommons.law.hofstra.edu/faculty_scholarship

Part of the Law Commons

\section{Recommended Citation}

Barbara Stark, Toward a Theory of Intercountry Human Rights: Global Capitalism and the Rise and Fall of Intercountry Adoption, 951365 (2020)

Available at: https://scholarlycommons.law.hofstra.edu/faculty_scholarship/1312

This Article is brought to you for free and open access by Scholarly Commons at Hofstra Law. It has been accepted for inclusion in Hofstra Law Faculty Scholarship by an authorized administrator of Scholarly Commons at Hofstra Law. For more information, please contact lawlas@hofstra.edu. 


\title{
Toward a Theory of Intercountry Human Rights: Global Capitalism and the Rise and Fall of Intercountry Adoption
}

\author{
BARBARA STARK $*$
}

CONTENTS

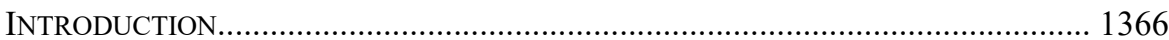

I. How THE COLD WAR SHAPED Human RightS ....................................... 1369

A. The Difference Between "American" and "International” Human

Rights

B. How the American Version of Human Rights Promoted Intercountry

Adoption

1. The Indian Adoption Project.............................................. 1374

2. Placing Black Children with White Families............................. 1376

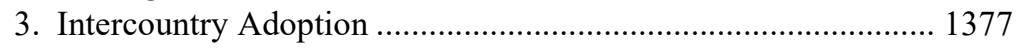

II. How Global CAPITALiSM CHANGED THE GAME ....................................... 1378

A. How Neoliberalism Reshaped Human Rights ................................... 1378

1. Individual Liberty and Freedom from Big Government ............ 1378

2. How Neoliberalism Transformed Adoption .............................. 1380

B. A Neoliberal Solution for Children in Crisis...................................... 1381

III. INTERCOUNTRY HuMAN RIGHTS FOR THE NEW GILDED AGE ...................... 1384

A. The New Gilded Age................................................................. 1384

1. The Global Recession ........................................................ 1384

2. Unprecedented Inequality ...................................................... 1385

B. Why Intercountry Adoption Requires Intercountry Human Rights ...... 1388

1. Why the Hague Convention Is Not Enough ............................ 1388

2. Human Rights Issues Raised by Adoption............................... 1388

a. Economic, Social, and Cultural Rights ............................. 1389

b. Nondiscrimination ............................................................. 1390

C. Intercountry Human Rights ............................................................ 1391



a. The Individual's Right to Petition ........................................ 1392

b. The States' Obligation ........................................................... 1393

c. The Fragmentation of International Law............................. 1393

* CBarbara Stark 2019. Professor of Law and Hofstra Research Fellow, Maurice A. Deane School of Law, Hofstra University. Early versions of this Article were presented at the Human Rights and Family Law Panel at the AALS Annual Meeting in New York; the Hofstra Faculty Workshop; the 7th World Congress on Family Law and Children's Rights, Dublin; the panel on Human Rights and the Trump Administration at the International Law Association, American Branch, International Law Weekend; and the ISFL North American Regional Conference on Inequality and the Future of Family Law. I am grateful to the participants, especially Peg Brinig, June Carbone, Maxine Eichner, Joanna Grossman, Marty Guggenheim, Maeve Harding, Jill Hasday, Julian Ku, Rachel Rebouche, and Jonathan Todres, for their comments. Research librarian Patricia Kasting provided invaluable research assistance. Hofstra Law School provided generous support. Thanks to Joyce Amore Cox for her skillful preparation of the manuscript and to Brittni Crofts Wassmer and Madalyn Clary for their meticulous editing. 
d. Resisting Neoliberalism ......................................................... 1394



a. The Individual's Right to Petition .......................................... 1396

b. The States' Obligation ….......................................................... 1396

CONCLUSION: TOWARD INTERCOUNTRY HUMAN RIGHTS................................... 1397

\section{INTRODUCTION}

Human rights, as set out in the International Bill of Rights roughly forty years ago, have not lived up to their drafters' hopes. ${ }^{1}$ Some argue that they have not come close. ${ }^{2}$ Even their champions recognize their limits. As Professor Philip Alston notes, "[i]n absolute figures, never have so many men, women, and children been subjugated, starved, or exterminated on the Earth." ${ }^{3}$ The shortcomings of human rights law are often blamed on weak enforcement. Because nation states resist restraints on their sovereignty, human rights law depends in large part on states policing themselves. On the international level, United Nations agencies and nongovernmental organizations (NGOs) monitor and report on human rights violations, but they have no authority to sanction violators or compel remedies.

This Article proposes another mechanism for enforcement, an alternative to selfserving domestic policing and weak international bureaucracy. "Intercountry," as opposed to "international," human rights would apply to specific rights in specific contexts and be enforceable through the legal mechanisms and other resources of the state parties that accepted them. ${ }^{4}$ Intercountry adoption is a useful context in which to consider this proposal for several reasons.

First, as a practical matter, there have probably never been more babies and children in orphanages, on the street, on the market, or on their own. ${ }^{5}$ Yet

1. The International Covenant on Economic, Social and Cultural Rights, Jan. 3, 1976, 993 U.N.T.S. 3 [hereinafter Economic Covenant]; and the International Covenant on Civil and Political Rights, Mar. 23, 1976, 999 U.N.T.S. 171 [hereinafter Civil Covenant]; together with G.A. Res. 217 (III) A, Universal Declaration of Human Rights (Dec. 10, 1948); comprise the International Bill of Rights, globally recognized as the definitive law of international human rights. DAvid Weissbrodt, Fionnuala Ní AolÁin, JoAn FitzPatrick \& FranK Newman, InTERnAtional Human Rights: LAw, Policy, AND Process 13-14 (4th ed. 2009).

2. See, e.g., Samuel Moyn, The Last Utopia: Human Rights in History (2010); Eric A. Posner, The Twilight of Human Rights Law (2014). The drafters set a high bar. See, e.g., Mary Ann Glendon, A World Made New: Eleanor Roosevelt and the Universal DeClaration of Human Rights 223 (2001). As John P. Humphrey pointed out, “Article One [of the UN Charter] puts the promotion of respect for human rights on the same level as the maintenance of international peace and security as a purpose of the United Nations." John P. Humphrey, The International Law of Human Rights in the Middle Twentieth Century, in THE Present State of International Law 75, 84 (Maarten Bos ed., 1973).

3. Philip Alston, Does the Past Matter? On the Origins of Human Rights, 126 HARV. L. REV. 2043, 2064 (2013).

4. See infra Sections III.C.1, III.C.2.

5. These categories are fluid, as babies and children move among them, and "orphanages" include group homes and other forms of nonfamily care. According to United Nations sources, there are 140 million orphans (defined as a child who has lost one or both 
intercountry adoptions have declined to levels not seen for almost forty years. ${ }^{6}$ Intercountry human rights would focus states on some of their most vulnerable people. They would also better protect would-be adoptive parents from a range of risks, from their children's trauma to their own unknowing complicity in serious human rights violations. ${ }^{7}$

Second, from a jurisprudential perspective, since virtually all of the states involved in intercountry adoption have ratified virtually all of the human rights instruments applicable in this context, the applicable human rights law is not in dispute. ${ }^{8}$ Receiving states and states of origin, moreover, presumably have a common goal - the best interest of the child. This is very different from the ideological conflict at the core of other interstate efforts to promote human rights, such as the Alien Tort Statute (ATS) litigation. ${ }^{9}$ Foreign support for human rights may also be more

parents). Orphans, UNICEF: PRESS CTR., www.unicef.org/media/media_45279.html [https://perma.cc/MQ87-3TKP] (last updated June 16, 2015). There are "up to 150 million street children." Street Children, UNESCO, https://wayback.archive-it.org/10611/2017020 5023736/http://portal.unesco.org/shs/en/ev.php-URL_ID=11403\&URL_DO=DO_TOPIC\& URL_SECTION=201.html [https://perma.cc/PLJ4-PWXU] (last updated Nov. 29, 2007); see also D. Marianne Blair, Merle H. Weiner, Barbara Stark \& Solangel Maldonado, FAMILY LAW IN THE WORLD COMMUNITY 825-29 (3rd ed. 2015) (noting that many street children have families and are not eligible for adoption). Experts estimate that thirty percent of all detected trafficked persons are children but are currently unable to reliably aggregate data. UNODC, Global Report ON Trafficking IN Persons 10 (2018), https://www.unodc.org/documents/data-and-analysis/glotip/2018/GLOTiP_2018_BOOK_we b_small.pdf [https://perma.cc/2DMT-498B]. The children "on their own" refer to children who are not living in families but are not included in these data.

6. Miriam Jordan, Foreign Adoptions by Americans Drop to Lowest Level Since 1982, WALl ST. J. (Apr. 1, 2015, 2:19 PM), https://www.wsj.com/articles/foreign-adoptions-by -americans-drop-to-lowest-level-since-1982-1427837631 [https://perma.cc/7LF6-MJRB]. According to Professor Peter Selman, there were a total of 8299 adoptions in 2018, compared to 43,860 in 2005. Peter Selman, Global Statistics for Intercountry Adoption: RECEIVING STATES AND STATES OF ORIGIN 2005-2018, at 2 (2019), https://assets.hcch.net/docs /a8fe9f19-23e6-40c2-855e-388e112bf1f5.pdf [https://perma.cc/78K7-6XQX].

7. These risks are not mutually exclusive. See, e.g., David M. Smolin, The Corrupting Influence of the United States on a Vulnerable Intercountry Adoption System: A Guide for Stakeholders, Hague and Non-Hague Nations, NGOs, and Concerned Parties, 15 UTAH L. REV. 1065 (2013) (describing his discovery that his adopted daughters were not, in fact, orphans); see also Russell Goldman, An Adoption Nightmare, ABC NEws (May 14, 2008, 9:08 AM), https://abcnews.go.com/International/story?id=4823713\&page=1 [https://perma.cc/AU 5Y-ZQK5] (describing the Smolins' ordeal).

8. These would include, in addition to the International Bill of Rights, see supra note 1, the Convention on the Rights of the Child, Sept. 2, 1990, 1577 U.N.T.S. 3 [hereinafter CRC], and the Convention on the Elimination of All Forms of Discrimination Against Women, Dec. 18, 1979, 1249 U.N.T.S. 13 [hereinafter CEDAW]. The United States, which has only ratified the Civil Covenant, is the conspicuous outlier. Agreement on the applicable human rights law might suggest that intercountry human rights are unnecessary, if not redundant. As noted above and explained below, however, ratification is not compliance.

9. Alien Tort Statute, 28 U.S.C. § 1350 (2012); see also infra Section III.C.1.c (discussing the ATS litigation). 
palatable when it involves family law, rather than ostensibly more important issues of trade or national security. ${ }^{10}$

Finally, from a more theoretical perspective, the rise and fall of intercountry adoption, from the 1950s to the present, demonstrates the deep tension between human rights and global capitalism. By "global capitalism" I refer to capitalism unrestrained by national laws or shared ethical codes, what David Brooks calls "naked capitalism." Intercountry adoption exposes the human costs of global capitalism in a specific, concrete, international context.

Part I of this Article describes the origins of the tension between human rights and global capitalism in the Cold War era, from the end of World War II to the collapse of the Soviet Union in the early 1990s. It explains how the American version of human rights veered off from the international version and why the American version prevailed. This Part also shows how the American version of human rights promoted intercountry adoption.

Part II explains how global capitalism changed the game. ${ }^{12}$ This Part focuses on the heyday of neoliberalism, from the elections of Ronald Reagan and Margaret Thatcher to the Great Recession beginning in 2008. It shows how neoliberalism reshaped human rights and produced a perverse "solution" for children in crisis.

Part III explains why intercountry adoption requires intercountry human rights. It begins by examining the unprecedented inequality that currently characterizes the global economy. It explains why the Hague Convention on Intercountry Adoption, ${ }^{13}$ enacted in the United States in 2008, cannot address the problems this creates for transborder adoptions. Rather, intercountry adoption requires the revival of the full panoply of international human rights and a fresh approach to their realization.

Part IV proposes a theory of intercountry human rights, drawing on the eighteenth-century philosopher Thomas Paine and the twenty-first-century economist Thomas Picketty. It explains how intercountry human rights would apply in the context of intercountry adoption and concludes by describing how intercountry human rights might operate in practice.

10. See Martha Minow, Forming Underneath Everything that Grows: Toward a History of Family Law, 1985 WIS. L. REV. 819, 819 (1985) (noting the low status of family law within the legal profession).

11. David Brooks, Opinion, Moral Vacuum in the House of Trump, N.Y. TIMES (July 14, 2017), https://nyti.ms/2uggqeR [https://perma.cc/2LUY-MQ77] (noting that, beyond loyalty to their own family, the Trumps have "no attachment to any external moral truth or ethical code. There is just naked capitalism."). This is, in part, what has made globalization so wildly lucrative - twenty-first century markets coupled with an absence of enforceable labor, human rights, or environmental laws last seen in the nineteenth century. I am not suggesting that all global enterprises lack such restraints, but they were in short supply in the major sending states described in Sections I.B.3 and II.B, infra.

12. Global capitalism, in its current iteration, was made possible by neoliberalism, which became a juggernaut in the 1990s and the first decade of the 2000's, particularly after the collapse of the Soviet Union. See infra Section II.A.

13. Convention on Protection of Children and Cooperation in Respect to Intercountry Adoption, May 29, 1993, 1870 U.N.T.S. 182. 


\section{HOW THE COLD WAR SHAPED HUMAN RightS}

Human rights were an idealistic "Never again!" to the horrors of the Holocaust and World War II. ${ }^{14}$ The international committee that drafted the Universal Declaration of Human Rights, chaired by Eleanor Roosevelt, drew on the Enlightenment and the French and American Revolutions to declare that everyonewhatever race, religion, or gender - was entitled to civil and political rights as well as economic, social, and cultural rights. ${ }^{15}$ Civil and political rights included the familiar constitutional rights to assemble, organize, protest, and vote. Economic, social, and cultural rights were less familiar to most Americans. They included rights to an adequate standard of living, health, education, and work. ${ }^{16}$

This Part first explains how the American version of human rights deviates from the international version. It then describes why the American version prevailed. Finally, it shows how this version of human rights promoted intercountry adoption.

\section{A. The Difference Between "American" and "International” Human Rights}

Although Americans had been among the earliest proponents of international human rights after World War II, by the time the Civil Covenant and the Economic Covenant came into force in $1976,{ }^{17}$ the United States had for all practical purposes abandoned the project. It had neither signed nor ratified either Covenant and was not represented on the committees charged with monitoring them.

The United States' rejection of international human rights was led in the 1950s by southern conservatives in Congress. They claimed that international human rights violated states' rights. ${ }^{18}$ What they meant was that the explicit prohibitions against

14. This is the conventional story. See, e.g., Louis Henkin, Sarah H. Cleveland, Laurence R. Helfer, Gerald L. Neuman \& Diane F. Orentlicher, Human Rights 135 (2d ed. 2009); Henry J. Steiner, Philip Alston \& Ryan Goodman, International Human Rights in Context: Law, Politics, Morals 133 (3d ed. 2008). It is a grand story, and has been told often, sometimes eloquently. See, e.g., Louis Henkin, The AgE Of Rights (1990); see also GLENDON, supra note 2.

15. GLENDON, supra note 2, at xvii.

16. See Economic Covenant, supra note 1, at art. 11 (standard of living); id. at art. 12 (health); id. at art. 13; id. at art. 14 (education); id. at art. 7 (work).

17. See supra note 1.

18. See, e.g., The International Convention on the Prevention and Punishment of the Crime of Genocide: Hearings Before the Subcomm. on the Genocide Convention of the S. Comm. on Foreign Relations, 81st Cong. 208 (1950) (statement of Carl B. Rix, Vice Chairman, Spec. Comm. on Peace and Law Through United Nations of the Am. Bar Ass'n).

[A]re we ready to surrender the power of the States over such matters to the Federal Government? ... The report of the Civil Rights Committee appointed by the President, after considering the division of power over civil rights between the Federal Government and the States, in two places refers to the added power which may be given to Congress in the field of civil rights if the human-rights treaty is ratified and approved.

Id. 
racial discrimination set out in the International Bill of Rights threatened still-legal segregation in the South. ${ }^{19}$ They were right.

They were able to prevent the United States from ratifying human rights treaties, but they could not prevent international political pressure. The Soviets distributed photographs of the police attacking civil rights marchers with fire hoses and German shepherds throughout the Third World..$^{20}$ People in the newly independent states throughout Asia and Africa were appalled. "Desegregation [became] a Cold War imperative," as legal historian Mary Duziak later showed. ${ }^{21}$

But international human rights law remained anathema in the United States. It did not ratify the Civil Covenant until 1992, ${ }^{22}$ after the fall of the Soviet Union. Even then, it did so with the caveat that the Civil Covenant is "non-self-executing," meaning that it does not operate as law in the United States and cannot be relied upon in U.S. courts. ${ }^{23}$

The American version of human rights remains limited to civil and political rights. The United States has still not ratified the Economic Covenant, which it equated with communism during the Cold War. ${ }^{24}$ The United States has long been wary of economic rights. ${ }^{25}$ It was the richest country in the world after World War II, and capitalism was its driving force, the engine of its prosperity. The myth that anyone willing to work hard could be successful in America persists. Long after the fall of

19. See id. For an overview of the efforts to apply the human rights provisions of the United Nations Charter in state and federal United States courts from 1946 to 1955, see Bert B. Lockwood, Jr., The United Nations Charter and United States Civil Rights Litigation: 19461955, 69 IOWA L. REV. 901, 902 (1984).

20. Vicki Goldberg, PHOTOGRAPHY VIEW; Remembering the Faces in the Civil Rights Struggle, N.Y. Times: Photography View (July 17, 1994), https://nyti.ms/298Aqrn [https://perma.cc/K8T3-RK6T].

21. Mary L. Dudziak, Desegregation as a Cold War Imperative, 41 StAN. L. Rev. 61, 62 63 (1988); see Brief for the United States as Amici Curiae at 7, Brown v. Board of Education (Brown I), 347 U.S. 483 (1954) (Nos. 8, 101, 191, 413, 448) ("Soviet spokesmen [are using the] ... undeniable existence of racial discrimination [as] . . propaganda warfare.").

22. See Civil Covenant, supra note 1 (entered into force Sep. 8, 1992). For the text of the Resolution of Ratification, see S. Exec. Doc. No. 102-23, at 21 (1992).

23. See Louis Henkin \& W. Michael Reisman, U.S. Ratification of Human Rights Conventions: The Ghost of Senator Bricker, 89 AM. J. INT'L L. 341, 341 (1995).

24. See Philip Alston, U.S. Ratification of the Covenant on Economic, Social and Cultural Rights: The Need for an Entirely New Strategy, 84 AM. J. INT'L L. 365 (1990).

25. I have set out the major reasons for this antipathy, at least on the federal level, in a series of articles. See, e.g., Barbara Stark, Deconstructing the Framers' Right to Property: Liberty's Daughters and Economic Rights, 28 Hofstra L. ReV. 963 (2000) (explaining how economic rights were ignored by the Framers); Barbara Stark, Postmodern Rhetoric, Economic Rights and an International Text: “A Miracle for Breakfast," 33 VA. J. INT'L L. 433 (1993) (explaining how economic rights were preempted by the rhetoric of opportunity); Barbara Stark, The Future of the Fourteenth Amendment and International Human Rights Law: The Black Heritage Trail, 13 TeMP. PoL. \& C.R. L. REV. 557 (2004) (explaining how racism shaped American perceptions of economic rights). On the state level, in contrast, economic rights have been widely embraced. See Barbara Stark, Economic Rights in the United States and International Human Rights Law: Toward an "Entirely New Strategy," 44 HASTINGS L.J. 79 (1992). 
the Soviet Union, Americans remain suspicious of socialism, ${ }^{26}$ although this may be changing. ${ }^{27}$

The American version of human rights has become the dominant model globally for two related but distinct reasons. First, the collapse of the Soviet Union eliminated the competition. The nonaligned states in the developing world could no longer play the communist Soviets and the capitalist Americans off against each other. ${ }^{28}$ The United States was the only remaining superpower. Second, neoliberal ideology has become ubiquitous..$^{29}$ According to the neoliberals, material well-being is best assured by free, unrestrained markets. ${ }^{30}$

\section{B. How the American Version of Human Rights Promoted Intercountry Adoption}

When parents cannot care for their infants, another member of the family or community usually steps up. According to historian Peter Conn, adoption is ancient and well-documented throughout the world. ${ }^{31}$ But legal adoption by strangers, in which all ties to the family of origin are severed, was rare until nineteenth century

26. See generally Mark Leibovich, Socialism! Boo, Hiss, Repeat, N.Y. TimES (Feb. 28, 2009), https://www.nytimes.com/2009/03/01/weekinreview/01leibovich.html [https://perma .cc/TU8S-G8BC] (noting that shortly after the Great Recession began, the "socialist bogeymantra has made a full-scale return after a long stretch of relative dormancy" as conservatives attack "bank bailouts, budget blowouts and stimulus bills").

27. See, e.g., Michelle Goldberg, Opinion, No Wonder Millennials Hate Capitalism, N.Y. TIMES, https://nyti.ms/2kq324J [https://perma.cc/E3CD-59C3] (Dec. 4, 2017) (citing a survey finding that " 44 percent of millennials would prefer to live in a socialist country, compared with 42 percent who wanted to live under capitalism"); Corey Robin, Opinion, The New Socialists, N.Y. TimeS (Aug. 24, 2018), https://nyti.ms/2BJj0io [https://perma.cc/853BBULZ] ("Public support for socialism is growing. Self-identified socialists like Bernie Sanders, Alexandria Ocasio-Cortez and Rashida Tlaib are making inroads into the Democratic Party ...."); Simon van Zuylen-Wood, Pinkos Have More Fun; Socialism Is AOC's Calling Card, Trump's Latest Rhetorical Bludgeon, and a New Way to Date in Brooklyn, N.Y. MAG. (Mar. 3, 2019), https://nymag.com/intelligencer/2019/03/socialism-and-young-socialists.html [https://perma.cc/V2LX-PZ86] ("Until very recently, it wasn't that socialism was toxic in a red-scare way. It was irrelevant, in a dust-bin-of-history way. But then came Bernie Sanders[] [and] ... the spectacular rise of Ocasio-Cortez. . . . For Ocasio-Cortez, Sanders, and most of their devotees, ..." socialism isn't a "planned economy that replaces market capitalism . . . [but a] robust version of New Deal liberalism — or, perhaps, Northern European social democracy.").

28. Robert Howse, The End of the Globalization Debate: A Review Essay, 121 HARV. L. REV. 1528, 1529 (2008) (noting the "new pro-market consensus").

29. I have explained the ubiquity of neoliberalism and the growing challenges to its hegemony elsewhere. See Barbara Stark, When Genealogy Matters: Intercountry Adoption, International Human Rights, and Global Neoliberalism, 51 VAND. J. TrANSNAT'L L. 159, 196-97 (2018) (Section IV.A.1 The Ubiquity of Neoliberalism). Its role in intercountry adoption is set out in Part II, infra.

30. See infra Part II.

31. See Peter Conn, Adoption: A Brief Social and Cultural History 27-56 (2013) (anecdotal accounts of adoption dating back to $1772 \mathrm{BCE}$ and documentation of adoptions from Mesopotamia through the Middle East, China, Europe, and Oceania). 
America. In Europe, the Church condemned adoption. ${ }^{32}$ The importance of blood ties and the maintenance of family registries discouraged the adoption of babies or children throughout Asia, with the exception of India. In Muslim states, stranger adoption was prohibited; orphans were the responsibility of relatives under kafalah. ${ }^{33}$ As Professor Barbara Melosh notes:

The emergence of modern adoption required a radically different understanding of family, one that overturned deeply held beliefs about blood and nurture, obligation and love, choice and chance. It was no accident that the United States was the crucible of this kind of adoption: in its repudiation of the past and its confidence in social engineering, adoption is quintessentially American. ${ }^{34}$

The American version of human rights, similarly, is quintessentially American. It remains limited to civil and political rights. From the beginning, the United States cut itself off from the broader, richer tradition of international human rights, as well as from the international institutions that nourished human rights and helped them develop. ${ }^{35}$ The United States still hasn't ratified the Economic Covenant, which recognizes the right of everyone to "an adequate standard of living," 36 and, more specifically, that the "widest possible protection and assistance should be accorded to the family." ${ }^{\prime 7}$ In the United States, poverty is not the state's responsibility-even poverty caused by the government itself. ${ }^{38}$ Rather, it is the responsibility of the family or the individual.

Nor has the United States ratified the Convention on the Rights of the Child $(\mathrm{CRC})^{39}$ - the only country in the world not to do so. The CRC, in addition to affirming the child's economic rights, explicitly recognizes the child's right to know her parents, to be part of a family and part of a community. ${ }^{40}$ Article 29 provides that

32. The Church preferred childless men of property to leave their property to the Church, rather than to adopt heirs. Id.

33. Id. at 55 .

34. Barbara Melosh, Strangers and Kin: The American Way of Adoption 15 (2002). Legal adoption served different interests over time, although there was always an altruistic component or rationale. Massachusetts was the first state to pass a comprehensive adoption law in 1851. David Ray Papke, Pondering Past Purposes: A Critical History of American Adoption Law, 102 W. VA. L. REV. 459, 461 (1999); see also Chris Guthrie \& Joanna L. Grossman, Adoption in the Progressive Era: Preserving, Creating, and Re-creating Families, 43 AM. J. LEGAL Hist. 235, 237 (1999) (noting that "at least four other states" had enacted less comprehensive statutes before Massachusetts).

35. These would include the committees responsible for monitoring the human rights treaties.

36. Economic Covenant, supra note 1, at art. 10.

37. Id. at art. 10 .

38. Laura Briggs, Somebody's Children: The Politics of Transracial and TransNational Adoption (2012) 59-93 (describing the United States' treatment of Native Americans).

39. See CRC, supra note 8.

40. See, e.g., Stark, supra note 29, at 189 (Section II.B.2(b) The Child's Right to Belong). 
education should be directed to "develop[ing] . . respect for [the child's] cultural identity, language and values." ${ }^{\prime 1}$

In the United States, in contrast, ethnic identity and the community values of nonwhite groups, including Native Americans and blacks, were historically viewed as inferior to majoritarian ("white") ethnicity and values. ${ }^{42}$ These identities and values, it was understood, were a cause of their poverty. From the state's perspective in the 1950s and 1960s, the best that could be done for a Native American or black child was to offer her a "fresh start," "free" of her culture and her community. The rights of the child to her culture and ethnicity, and the rights of the community to their children, were not a factor because they were not viewed as "rights" in the United States.

This is not to suggest simple causality here; the United States didn't recognize these rights for the same overdetermined reasons it didn't ratify the instruments in which they were set out. These include pervasive racism and a rarely questioned belief in the superiority of Western civilization. ${ }^{43}$ The substance of those rights, moreover, has evolved significantly since the 1960 s, when the Covenants were drafted, and the 1970s, when they came into force. But the early, and ongoing, resistance of the United States cut it off from this development. Thus, although Canada's treatment of its indigenous children was similar to that of the United States, Canada, which has ratified these instruments, has since apologized to its indigenous people and promised millions in reparations. ${ }^{44}$

41. CRC, supra note 8, at art. 29.

42. There is a vast literature addressing what Ian Haney Lopez has called "the legal construction of race." See, e.g., IAN HANEY LÓPEZ, White By LAW: The LEGAL CONSTRUCTION OF RACE (rev. and updated, 10th anniversary ed. 2006) (analyzing ways in which race is legally constructed); see also Ian Haney LÓpez, Dog Whistle Politics: How Coded Racial Appeals Have Reinvented Racism and Wrecked the Middle Class (2014). For thoughtful analyses of the construction of race in the context of adoption, see, for example, infra Sections I.B.1-3 and accompanying footnotes. See also Kai Jackson \& Catherine E. McKinley, Sisters: A Reunion Story, in The Adoption Reader: Birth Mothers, Adoptive Mothers and Adopted Daughters Tell Their Stories 190, 191-97 (Susan Wadia-Ells ed., 1995) (describing adoptee's discovery that her biological father was white). For compelling accounts of the process through which African American communities have reclaimed and affirmed their community values, see Anthony Alfieri's series of articles on community organizing in Miami, especially Anthony V. Alfieri, Resistance Songs: Mobilizing the Law and Politics of Community, 93 TeX. L. ReV. 1459, 1463 (2015) (reviewing LeA VANDERVELde, Redemption Songs: Suing FOr FreEdom Before Dred Scott (2014)) (drawing on VanderVelde's work to consider "how to engage the diverse members of a community in 'really getting a sense of who they are"'), and Anthony V. Alfieri, Inner-City Anti-Poverty Campaign, 64 UCLA L. REV. 1374, 1374 (2017) (describing a "Third Wave of anti-poverty campaigns . . . [grounded in] 'experiential reflection"').

43. Asked what he thought of Western civilization, Gandhi supposedly replied, "I think it would be a good idea." Salil Tripathi, Opinion, Meanwhile: Gandhi, for One, Would Have Found It Funny, N.Y. Times (Jan. 21, 2004), https://www.nytimes.com/2004/01/21/opinion /meanwhile-gandhi-for-one-would-have-found-it-funny.html [https://perma.cc/B2KLUHYM].

44. Ian Austen, Canada to Pay Millions in Indigenous Lawsuit Over Forced Adoptions, N.Y. Times (Oct. 6, 2017), https://nyti.ms/2yLyaxm [https://perma.cc/676D-BYAZ]; Ian 
The American failure to recognize poverty, ethnic identity, and community values as human rights issues led well-intentioned reformers to promote disastrous domestic policies. These include the Indian Adoption Project and the often-ill-considered placement of black children with white families, as described below. Intercountry adoption was a natural extension of these policies.

\section{The Indian Adoption Project}

By the 1950s, Native Americans were among the poorest people in the country. ${ }^{45}$ The Indian Adoption Project was conceived as a solution to the "Indian problem." As a local official explained:

If you want to solve the Indian problem you can do it in one generation. You can take all of our children of school age and move them bodily out of the Indian country and transport them to some other part of the United States. Where there are civilized people ... [.] If you take these kids away and educate them to make their own lives, they wouldn't come back here. ${ }^{46}$

The Indian Adoption Project, initiated in 1958 and ending in 1968, placed children "far from the reservation, geographically as well as culturally." ${ }^{47}$ The Project placed 395 Indian children with white families. ${ }^{48}$

But the purpose of the federally sponsored Project was to prime the pump, to encourage "the adoption of American Indian children on a nation-wide basis." 49 It was a success. Since the demand for adoptees exceeded Project capacity, agencies in the children's home states arranged for their adoptions. By the early 1970s, between twenty-five and thirty-five percent of Native American children had been legally adopted by white families. ${ }^{50}$

Austen, Trudeau Apologizes for Abuse and 'Profound Cultural Loss' at Indigenous Schools, N.Y. Times (Nov. 24, 2017), https://nyti.ms/2i45Y6g [https://perma.cc/P4BH-P6Q7].

45. Native American holdings shrank from 138 million acres of treaty land in 1887 to 48 million acres in 1934, 20 million acres of which were desert or semi-desert. This can be attributed to over two hundred years of legalized property theft, genocidal policies, and unscrupulous treatment by the United States government, including the failure to comply with the treaties the United State itself had forced on them. BRIGGS, supra note 38, at 69.

46. Lila J. George, Why the Need for the Indian Child Welfare Act?, in THE CHALlenge of Permanency Planning in a Multicultural Society 165, 169 (Gary R. Anderson, Angela Shen Ryan \& Bogart R. Leashore eds., 1997) (quoting Edward Rogers, Proceedings of Minnesota Indian Conference (Apr. 11, 1950) (on file at Univ. of Minn., Bemidji, Social Welfare History Archives)).

47. Id. at 169; see also DAVID FAnSHEL, FAR FROM the RESERVATION: THE TrANSRACial Adoption of AMERICAN INDIAN CHILDREN (1972).

48. George, supra note 46, at 169.

49. FANSHEL, supra note 47 , at 35 .

50. George, supra note 46, at 172-73. The point was to "kill the Indian in [them.]' This meant cutting their hair, teaching them Christianity, and forcing them to speak English." Gabby Deutch, A Court Battle Over a Dallas Toddler Could Decide the Future of Native 
Their families, as well as their tribes, were devastated by the children's removal. As Congress explicitly recognized when it passed the Indian Child Adoption Welfare Act of 1978 (ICWA) ${ }^{51}$ :

[T] here is no resource that is more vital to the continued existence and integrity of Indian tribes than their children ... [and] an alarmingly high percentage of Indian families are broken up by the removal, often unwarranted, of their children from them by nontribal public and private agencies and ... an alarmingly high percentage of such children are placed in non-Indian foster and adoptive homes and institutions . . . ${ }^{52}$

In Mississippi Band of Choctaw Indians v. Holyfield, ${ }^{53}$ the Supreme Court examined the jurisdictional provisions "[a]t the heart of the ICWA." ${ }^{54}$ In Holyfield, the parents, both members of the tribe, made sure that their illegitimate twin infants were never physically present on the reservation, and voluntarily placed them with non-Indian adoptive parents. The Court held that the ICWA established exclusive jurisdiction in the tribal courts over Indian children domiciled there, and that the "domicile of origin" for Indian babies was that of their mother. ${ }^{55}$

In a more recent decision, Adoptive Couple v. Baby Girl, ${ }^{56}$ however, the Supreme Court held that the ICWA did not bar the adoption of an Indian baby by non-Indians where her Indian father had never had physical or legal custody of her. ${ }^{57}$ This ruling returned the Indian father's two-year-old daughter to the white couple who had adopted her, from whom she had been removed by a prior court order. As Justice Sotomayor noted in her dissent, the decision undercut the purpose of the ICWA,

American Law, ATLANTIC (Feb. 21, 2019), https://www.theatlantic.com/family/archive/2019 /02/indian-child-welfare-acts-uncertain-future/582628/ [https://perma.cc/LJ3T-BPGS].

51. 25 U.S.C. $\S \S 1901-1963$ (2012). The purpose of the ICWA is to protect the best interests of Indian children and to promote the stability and security of Indian tribes and families by the establishment of minimum Federal standards for the removal of Indian children from their families and the placement of such children in . . homes which will reflect the unique values of Indian culture ....

Id. $\S 1902$.

52. Id. § 1901(3)-(4). Congress explicitly noted, "that the States, exercising their recognized jurisdiction over Indian child custody proceedings through administrative and judicial bodies, have often failed to recognize the essential tribal relations of Indian people and the cultural and social standards prevailing in Indian communities and families." Id. § 1901(5).

53. 490 U.S. 30 (1989).

54. $I d$. at 36 .

55. Id. at 48; see also Barbara Ann Atwood, Flashpoints Under the Indian Child Welfare Act: Toward a New Understanding of State Court Resistance, 51 EMORY L.J. 587, 625-42 (2002) (criticizing the "existing Indian family" exception); Solangel Maldonado, Race, Culture, and Adoption: Lessons from Mississippi Band of Choctaw Indians v. Holyfield, 17 COLUM. J. GENDER \& L. 1, 27 (2008) (noting that the ICWA privileges biology over social, legal, or political identification for purposes of determining who is Native American).

56. 570 U.S. 637 (2013).

57. Id. at $647-51$. 
which "protects not only Indian parents' interests but also those of Indian tribes." 58 The majority retreated from the recognition of the importance of children to their communities, set out in the ICWA and confirmed in Holyfield.

\section{Placing Black Children with White Families}

In 1954 Congress amended the Social Security Act to allow agricultural and domestic workers to qualify for Aid to Families with Dependent Children (AFDC) ${ }^{59}$ This made black women and children in the South eligible for welfare under federal law. ${ }^{60}$ In response, Mississippi enacted state-wide rules banning benefits for "immoral" or "unsuitable" households, striking thousands of "illegitimate" children from state welfare rolls. ${ }^{61}$ Florida took similar steps, excluding 14,000 from benefits in $1959 .{ }^{62}$ Blaming black mothers for black poverty was also an effective strategy for discrediting the civil rights movement. ${ }^{63}$ Northern liberals respected peaceful protestors in suits and ties, but had little sympathy for unwed mothers. ${ }^{64}$

Arthur Flemming, the Secretary of the federal agency responsible for administering AFDC, tried to counter these state rules by prohibiting states from cutting benefits unless they provided alternatives for the affected children. ${ }^{65}$ Everyone understood that foster care or orphanages would be much more expensive for the state. ${ }^{66}$ But Flemming's plan backfired.${ }^{67}$ Rather than discouraging states from denying benefits to single black mothers, it discouraged these mothers from applying for benefits, since by doing so they risked losing their children. ${ }^{68}$ These mothers remained poor, but their families stayed together. ${ }^{69}$

58. Id. at 688-89; see also Jan Hoffman, Who Can Adopt a Native American Child? A Texas Couple vs. 573 Tribes, N.Y. TIMES (June 5, 2019), https://www.nytimes.com/2019/06/ 05/health/navajo-children-custody-fight.html [https://perma.cc/92JT-RNLG]. A Texas ruling by federal judge Reed O'Connor, Northern District of Texas, holds the ICWA unconstitutional because it requires Texas to apply federal law to its own domestic relations case. Id. An appeal is pending from the Court of Appeals for the Fifth Circuit. Id.

59. Social Security Act Amendments of 1954, ch. 1206, 68 Stat. 1052 (codified as amended in scattered sections of 42 U.S.C.).

60. BRIGGS, supra note 38 , at 39 .

61. Id.

62. Id.

63. See, e.g., Daniel P. Moynihan, Office of Policy Planning \& Research, U.S. DeP'T of Labor, The Negro Family: The Case for National Action (1965).

64. BRIGGS, supra note 38 , at 8 . As Briggs explains, "segregationists tried to make an issue of unwed black mothers and their bastard children to counter the image of black dignity and respectability" projected by Martin Luther King Jr. and other civil rights activists. Id.

65. Act of May 8, 1961, Pub. L. No. 87-31, 75 Stat. 75 (codified as amended in 42 U.S.C. 601-660).

66. BRIGGS, supra note 38 , at 42.

67. See id.

68. Id.

69. See id. 
In the 1990s, then-President Bill Clinton promised to "end welfare as we know it." ${ }^{\prime 70}$ In 1996, Congress passed the Personal Responsibility and Work Opportunity Reconciliation Act, which replaced AFDC with Temporary Assistance for Needy Families (TANF). ${ }^{71}$ The new law also put a federal lifetime cap of five years on welfare, although states were allowed to set even shorter limits. ${ }^{72}$

A year later, in 1997, Clinton signed the Adoption and Safe Families Act (ASFA) ${ }^{73}$ which aimed "to double the number of foster children adopted annually to 54,000 by $2002 . " 74$ The ASFA requires a "permanency hearing" to be held within one year after a child is put in foster care. ${ }^{75}$ If the child is still in foster care three months later-with specific exemptions for relative care, the agency's failure to make reasonable efforts at reunification, or some other "compelling reason"- the agency is expected to commence termination proceedings. ${ }^{76}$ The federal government also pays states bonuses for children adopted above the state baseline. ${ }^{77}$ In 1999 there were 46,000 adoptions and states received twenty million dollars in adoption bonuses. ${ }^{78}$ As Professor Dorothy Roberts notes, the "number of children in foster care . . doubled . . . from 262,000 in 1982 to 568,000 in 1999." 79 By 2000, fortytwo percent of the children in foster care were black, even though only seventeen percent of American children were black. ${ }^{80}$

\section{Intercountry Adoption}

International adoption began after World War II with Pearl S. Buck's work to save children in China from the chaos of the revolution, poverty, and communism. ${ }^{81}$ After adopting seven children herself, Buck opened her own agency, Welcome House, when she was unable to place two mixed-race children with any of the

70. See, e.g., Alana Semuels, The End of Welfare as We Know It, AtLAnTIC (Apr. 1, 2016), https://www.theatlantic.com/business/archive/2016/04/the-end-of-welfare-as-we-kn ow-it/476322/ [https://perma.cc/7VG6-K5A3]; see infra Section II.A.2.

71. Personal Responsibility and Work Opportunity Reconciliation Act of 1996, Pub. L. No. 104-193, 110 Stat. 2105 (codified as amended in scattered sections of U.S.C.).

72. Id. $\S 103,110$ Stat. 2112.

73. Adoption and Safe Families Act of 1997, Pub. L. No. 105-89, 111 Stat. 2115 (codified as amended in scattered sections of 42 U.S.C.).

74. Dorothy Roberts, Shattered Bonds: The Color of Child Welfare 105 (2002).

75. Id. at $109-10$.

76. Id. at 110 .

77. Id. Baselines are determined by average adoptions between 1995 and 1997. Id.

78. Id. at 111 .

79. Id. at 8 .

80. Id.

81. Id. at 151. Best-selling author of the Pulitzer Prize-winning novel The Good Earth and over seventy other books, and the first American woman to win the Nobel Prize in literature, Buck was the first celebrity to use her fame to publicize international adoption. See Brief Biography of Pearl S. Buck, PENN ARTS \& SCI., https://www.english.upenn.edu /Projects/Buck/biography.html [https://perma.cc/W7ZC-MWC5]. 
existing agencies..$^{82}$ After the Korean War, Harry and Bertha Holt saw a movie at an evangelical church about war orphans and were able to get a special act of Congress allowing them to adopt eight Korean orphans. ${ }^{83}$ The Holts were saving the children for Jesus. ${ }^{84}$ They, too, went on to establish an international adoption agency. ${ }^{85}$ Buck and the Holts were part of a triumphant, prosperous, postwar America that was ready to save the world.

\section{How Global CApitalism Changed the Game}

\section{A. How Neoliberalism Reshaped Human Rights}

\section{Individual Liberty and Freedom from Big Government}

Neoliberalism began as the response of conservative economists Frederick Hayak and Milton Friedman to the progressive social welfare policies of Franklin Delano Roosevelt in the United States and Clement Atlee in the United Kingdom. ${ }^{86}$ Hayak and Friedman felt that individual liberty was threatened by government regulations. ${ }^{87}$ Instead of state bureaucrats trying to manage the economy, they argued, markets should be left free to draw on the energy and genius of individual market actors. ${ }^{88}$ Their emphasis on "liberty" extended outward, to foreign states and "freedom fighters" resisting socialism, ${ }^{89}$ and inward, to the remnants of New Deal domestic policies which, they argued, created a dependent "underclass." 90

82. See ConN, supra note 31, at 116-17 (" $[\mathrm{I}] \mathrm{n}$ the sixty-plus years since Welcome House and similar organizations began their work, upwards of 800,000 children have come to the U.S. for adoption.").

83. BRIGgS, supra note 38, at 153; see also Bertha and Harry Holt, AdOPTION Hist. PROJECT, https://pages.uoregon.edu/adoption/people/holt.htm [https://perma.cc/8EZGXRDW] (last updated Feb. 24, 2012). As John Seabrook describes it: "Images of Holt getting out of the plane, surrounded by babies, were published in newspapers and magazines across the country. (Life ran a feature showing the Holt clan at home on the farm in Creswell in its 1955 Christmas issue.)" John Seabrook, The Last Babylift, New Yorker (May 3, 2010), https://www.newyorker.com/magazine/2010/05/10/the-last-babylift.

84. See Bertha and Harry Holt, supra note 83 ("The Holts believed they were doing God's work ...."). The only requirements for prospective parents were that they were "saved" and could afford the children's airfare from Korea. Id.

85. Id.

86. See generally Pierre Dardot \& Christian Laval, The New Way of the World: ON NEO-LIBERAL SOCIETY 49-73 (Gregory Elliott trans., 2013) (2009).

87. Daniel Stedman Jones, Masters of the Universe: Hayak, Friedman, and the Birth of NeOliberal Politics 2-3 (2012).

88. Id. at 332 .

89. This included CIA support for the Contras in Nicaragua. See Military and Paramilitary Activities in and Against Nicaragua (Nicar. v. U.S.), Judgment, 1986 I.C.J. Rep. 14 (June 27).

90. JONES, supra note 87, at 26. 
Neoliberal reforms were adopted after the widespread economic crises in the 1970s, when Keynesian prescriptions no longer seemed to work. ${ }^{91}$ Neoliberalism came into its own after the elections of Margaret Thatcher in 1979 and Ronald Reagan in $1981 .{ }^{92}$ They agreed that big government was the enemy. The first step was to eliminate bureaucratic regulations that shackled businesses. ${ }^{93}$ This included environmental as well as health and safety regulations. ${ }^{94}$

The second step was to eliminate social safety nets. Social welfare programs were slashed. ${ }^{95}$ Welfare - even TANF's temporary assistance for needy families - and health-care benefits (in the United States) were gutted or eliminated. ${ }^{96}$ Such programs perpetuated dependency. Without such incentives, the neoliberals argued, people would get jobs or start businesses..$^{97}$ In contrast to Roosevelt's unifying appeals to all of those "down on their luck," President Reagan called persistent poverty a scam, in which some Americans exploited others. His account was divisive and racist, suggesting that black "“welfare queens' . . . decked out in furs, [drove] Cadillac[s] to the welfare office to pick up [their] $\operatorname{check[s]."}{ }^{, 98}$

91. See id. at 119-220; David Harvey, A Brief History of NeOliberalism 57 (2005) ("[T] been for the serious crisis of capital accumulation during the 1970s.").

92. See Jones, supra note 87 at 268.

93. David M. Kotz, The Rise and Fall of Neoliberal Capitalism 15-18 (2015); see also Susan Marks, Four Human Rights Myths 8 (London Sch. of Econ. \& Political Sci. Law Dep't, Working Paper No.10/2012, 2012) (noting "the rise . . of the neo-liberal version of 'private' capitalism, with its now familiar policy prescription of privatisation, deregulation and state retreat from social provision").

94. Kotz, supra note 93, at 17-19.

95. See, e.g., Andrew Glass, Clinton Signs 'Welfare to Work' Bill, Aug. 22, 1996, Politico (Aug. 22, 2018, 12:09 AM), https://www.politico.com/story/2018/08/22/clintonsigns-welfare-to-work-bill-aug-22-1996-790321 [https://perma.cc/RA8Q-H9WM] (discussing legislation that "ended welfare as an entitlement program[,] required recipients to begin working after two years of receiving benefits[, and] placed a lifetime limit of five years on benefits paid by federal funds ... "). Clinton said, "[It] gives us a chance we haven't had before to break the cycle of dependency that has existed for millions and millions of our fellow citizens." Id.

96. Id.

97. See JONES, supra note 87 , at 268.

98. See Kathryn J. Edin \& H. Luke Shaefer, Ronald Reagan's “Welfare Queen” Myth: How the Gipper Kickstarted the War on the Working Poor, SALON (Sept. 27, 2015, 7:59 PM), https://www.salon.com/test/2015/09/27/ronald_reagans_welfare_queen_myth_how_the_gipp er_kickstarted_the_war_on_the_working_poor/ [https://perma.cc/V46S-V5ZR] ("None of these stereotypes even came close to reflecting reality, particularly in regard to race."); see also Josie Foehrenbach, Recent Publications, 19 HARV. C.R.-C.L. L. REV. 261, 261-62 (1984) (reviewing Frances Fox Piven \& Richard A. Cloward, The New Class War: Reagan's Attack on the Welfare State And Its Consequences (1982)) ("Reagan's attack on welfare state income maintenance programs . . represents one element of a comprehensive strategy designed to enlarge business profits and achieve a massive upward redistribution of income.”). In his recent book, The Queen, Josh Levin describes the life of Linda Taylor, the inspiration for Reagan's stereotype. JoSH LEVIN, THE QUEEN (2019). As Sam Dolnick notes in his review, "Reagan's stereotype was sweeping and offensive, but the woman at the center of it did drive a Cadillac and wear fur coats and take advantage of state programs intended to 
The neoliberals' third step was the privatization of the public sector. ${ }^{99}$ Once public functions, such as maintaining parks and prisons, were outsourced to private companies. Responsibility for dependent individuals, including children, the elderly, and the disabled, was left to their families. Adoption, too, was privatized, as explained below. ${ }^{100}$

But neoliberalism is not just a set of economic policies, as political theorist Wendy Brown explains. ${ }^{101}$ Rather, it is a "normative order of reason developed over three decades into a widely and deeply disseminated governing rationality, [which] transmogrifies every human domain and endeavor, along with humans themselves . ..." ${ }^{102}$ Neoliberalism, she explains, rejects the idea that humanity can "craft and steer its existence or even to secure its future." 103 For neoliberals, the free market, unrestrained by irrational humans and free of onerous regulations, is our best collective hope.

\section{How Neoliberalism Transformed Adoption}

Adoption in America has been transformed during the past few decades, reflecting an increase in births to unmarried white women, the decreasing stigma for such births, easier access to contraception, the greater autonomy of birth mothers, and an increase in "open" adoptions. ${ }^{104}$ In open adoptions, either or both birth parents are known to the adopting parents, and often expect to have some kind of ongoing relationship with the child. During this same period, growing numbers of black children have entered the foster care system. ${ }^{105}$ The ASFA made them available for adoption on an accelerated basis. ${ }^{106}$ The Multiethnic Placement Act ${ }^{107}$ made them available for adoption by white parents, despite the longstanding opposition of the National Association of Black Social Workers. ${ }^{108}$

help the poor." Sam Dolnick, The Life and Crimes of America's Original 'Welfare Queen,' N.Y. TiMES (May 20, 2019) (emphasis in original), https://www.nytimes.com/2019/05/20 /books/review/josh-levin-queen-linda-taylor.html. Dolnick concludes that she was "a singular American scoundrel who represented nothing but herself." Id.

99. KotZ, supra note 93, at 22.

100. See infra Section II.A.2.

101. See Wendy Brown, Undoing the Demos: Neoliberalism's Stealth Revolution $30(2015)$.

102. Id. at 9. Brown draws on Foucault here, for the notion of "normative reason" as an "[ascendant] governing rationality" that imposes "economic values, practices, and metrics to every dimension of human life." Id. at 30 .

103. Id. at 221.

104. See, e.g., Lisa Belkin, Now Accepting Applications for My Baby, N.Y. TIMES MaG. (Apr. 5, 1998), https:/www.nytimes.com/1998/04/05/magazine/now-accepting-applications -for-my-baby.html [https://perma.cc/QNW8-7FM3] (describing the process through which a birth mother selects the legal parents of her baby).

105. See supra Section I.B.2.

106. See supra notes 71-73.

107. Howard M. Metzenbaum Multiethnic Placement Act of 1994, Pub. L. No. 103-382, 108 Stat. 4056 (codified as amended in scattered sections of 42 U.S.C.).

108. Nat'l Ass'n of Black Social Workers, Position Statement on Trans-Racial Adoptions, (Sept. 1972), reprinted in Rita James Simon \& Howard Altstein, Transracial Adoption 
The increase in the number of surrendering mothers choosing open adoption, along with the declining number of available babies, contributed to a surge in intercountry adoption by parents unable to adopt domestically, or unwilling to enter into an open relationship with birth parents or to adopt black children. Intercountry adoption enabled these parents to adopt babies or toddlers, usually without ever meeting the birth parents, as described below. ${ }^{109}$ Intercountry adoption became more appealing for some, and the only option for many.

\section{B. A Neoliberal Solution for Children in Crisis}

Free market fundamentalism shaped international trade and development through the Washington Consensus ${ }^{110}$ Its gospel was "that the implementation of efficiency enhancing rules is an uncontentious goal, that everyone stands to gain from free trade, that property and contract rights are the paramount legal entitlements, and that rulebased regimes "level the playing field" and ensure fairness among otherwise unequal parties." 111 This became the driving force of neoliberal globalization. The promise was that global poverty would be reduced and eventually eliminated by economic growth through trade. ${ }^{12}$

The Washington Consensus promised to generate prosperity; new businesses would be spurred by an influx of Western cash. In countries like Vietnam, however, where the annual income was $\$ 800$, Western agencies offering fifty dollars for "facilitating" adoptions or as "finders fees" promoted baby selling. ${ }^{113}$ The local

50-52 (1977); see also Richard Tessler, Gail Gamache \& Liming LiU, West Meets East: AMERICANS ADOPT CHINESE CHILDREN 8 (1999) ("U.S. domestic transracial adoptions have been objected to since 1972 by the National Association of Black Social Workers on the grounds that to deny black children their heritage and their identification as AfricanAmericans . . . is to commit a form of genocide."); Twila L. Perry, Transracial and International Adoption: Mothers, Hierarchy, Race, and Feminist Legal Theory, 10 Yale J.L. \& FEMINISM 101 (1998).

109. See infra Section II.B.

110. Robin Broad \& John Cavanaugh, The Death of the Washington Consensus, 16 WORLD POL'Y J. 79, 79 (1999); see also JONES, supra note 87, at 8, 332.

111. Kerry Rittich, Enchantments of Reason/Coercions of Law, 57 U. MiAmI L. REV. 727, 739-40 (2003).

112. See Arturo Escobar, Encountering Development: The Making and Unmaking OF THE THIRD WORLD 21-24 (2012).

113. These fees, modest by Western standards, may tempt local officials to cut corners. E. J. Graff, The Lie We Love, ForEIGN POL'Y (Oct. 6, 2009, 5:14 PM), https://foreignpolicy.com /2009/10/06/the-lie-we-love/ [https://perma.cc/5T3N-CW8M]; BLAIR ET AL., supra note 5, at 828; see also, e.g., Richard A. Posner, The Regulation of the Market in Adoptions, 67 B.U. L. REV. 59, 60 (1987) (“Adoption agencies charge fees, often stiff ones, to adoptive parents, and part of the agencies' fee income goes to pay the medical expenses and other maintenance expenses of the natural mother; thus the adoptive parents pay the natural mother, albeit indirectly and at a regulated price, to give up her child. In "independent" adoptions, which are arranged through a lawyer or obstetrician, the element of sale is even more transparent ...."). Babies, similarly, have been viewed as "exports." Robert S. Gordon, The New Chinese Export: Orphaned Children--An Overview of Adopting Children from China, 10 TRANSNAT'L LAW. 121 (1997). 
people urging their friends or cousins to surrender their babies for cash were "entrepreneurs." There were no social safety nets to assure that families had food, shelter, or healthcare. There were no regulations governing orphanages or adoption services, no standards to which those purporting to provide such services could be held. In Cambodia, for example, investigators described a shack with a handwritten sign, "Orphanage," and babies lying in their own waste in rusty cribs. ${ }^{114}$

The numbers of babies and young children adopted increased steadily after the end of the Cold War, peaking in 2004, when roughly 45,000 babies were adopted internationally, half of whom came to the United States. ${ }^{115}$ But as Nigel Cantwell, an expert on child welfare and adoption systems in Eastern Europe and Central Asia, explained: "There are simply not enough healthy, adoptable infants to meet Western demand - and there's too much Western money in search of children. As a result, many international adoption agencies work not to find homes for needy children but to find children for Western homes." ${ }^{116}$ Asked how many healthy babies would be "available for international adoption if money never exchanged hands," Cantwell replied, "I would hazard a guess at zero." 117

The disparity between supply and demand resulted in widespread trafficking, which has been documented in countries of origin, including Cambodia, Guatemala, Nepal, Vietnam, India, and, on a smaller scale, in Haiti, Sierra Leone, Congo, and Uganda. ${ }^{118}$ In addition, there have been allegations of corruption in China, Russia, and South Korea. ${ }^{119}$ Some of these cases involved agencies lying to parents, telling them, for example, that their children would be educated in America and would send for their parents when they were older. ${ }^{120}$ In other cases, children were simply abducted. ${ }^{121}$

As these abuses were exposed, programs were shut down or put on hold. Some receiving states imposed moratoria, refusing to accept children from states that did

114. D. Marianne Blair, Safeguarding the Interests of Children in Intercountry Adoption: Assessing the Gatekeepers, 34 CAP. U. L. REV. 349, 356-58 (2005).

115. Elizabeth Bartholet, International Adoption: The Human Rights Position, 1 GLOBAL POL'Y 91, 92, 95 (2010).

116. Graff, supra note 113.

117. Id.

118. BLAIR ET AL., supra note 5, at 825-29; see also Elizabeth Bartholet, International Adoption: The Human Rights Issues, in BABy Markets: Money and the New Politics of Creating FAmilies 94 (Michele Bratcher Goodwin ed., 2010); Peter Selman, The Rise and Fall of Intercountry Adoption in the 21st Century: Global Trends from 2001 to 2010, in INTERCOUNTRY AdOPTION 7 (Judith L. Gibbons \& Karen Smith Rotabi eds., 2012); Sara Dillon, Making Legal Regimes for Intercountry Adoption Reflect Human Rights Principles: Transforming the United Nations Convention on the Rights of the Child with the Hague Convention on Intercountry Adoption, 21 B.U. INT'L L.J. 79 (2003); Shani M. King, Owning Laura Silsby's Shame: How the Haitian Child Trafficking Scheme Embodies the Western Disregard for the Integrity of Poor Families, 25 HARV. HuM. RTS. J. 1 (2012); Smolin, supra note 7 .

119. BLAIR ET AL., supra note 5, at 825 .

120. Id.

121. Id. at 829 . 
not comply with the Hague Convention standards. ${ }^{122}$ Intercountry adoptions have plummeted. In 2017, there were only 4714 international adoptions to the United States. ${ }^{123}$

Some argue that it will always be better for a child to be raised in the affluent West, even if she is raised in a family and community where she is the only child of color. ${ }^{124}$ But adoptees from Korea have described the racism confronting them in white suburbs and the white parents reluctant to acknowledge it. ${ }^{125}$ Black adoptees have described their sense of isolation and their difficulties "fitting in" with black as well as white communities. ${ }^{126}$ As the National Association of Black Social Workers has insisted since the 1970s, integration should not be the responsibility of children of color. ${ }^{127}$ In the United States, however, these are viewed as policy considerations rather than human rights issues. They were explicitly rejected in the Multiethnic Placement Act, which bars placement based on ethnicity. ${ }^{128}$

122. Termination was often abrupt, leaving would-be adoptive parents in limbo. See, e.g., Rachel L. Swarns, A Family, for a Few Days a Year, N.Y. Times (Dec. 8, 2012), https:/www.nytimes.com/2012/12/09/world/americas/stalled-adoption-program-in-guatemal a-leaves-families-in-limbo.html?pagewanted $=1 \&$ r $=0 \&$ ref $=$ world $\quad[$ https://perma.cc/JQK5M249] (describing the Carrs, who traveled nine times to Guatemala, trying to expedite the adoption of Geovany, who they met as a toddler). Several states objected to Guatemala's accession to the Hague Convention on the ground that it was unable to comply with its requirements. See Status Table, Hague Conference ON Private InT'L LAw, http://www.hcch.net/en/instruments/status-table [https://perma.cc/F6TS-WV6G] (noting objections of five states). Closing troubled adoption programs may still leave children at risk. See Azam Ahmed, A Locked Door, a Fire and 41 Girls Killed as Police Stood by, N.Y. TimES (Feb. 14, 2019), https://www.nytimes.com/2019/02/14/world/americas/guatemala-shelterfire-trial.html [https://perma.cc/V29J-DK7S] (describing a fatal fire in a group home for atrisk children in Guatemala).

123. U.S. State Dep'T, Annual Report on Intercountry Adoption Narratives 1 (2017).

124. See, e.g., Bartholet, supra note 118, at 94. See generally Kim Forde-Mazrui, Black Identity and Child Placement: The Best Interests of Black and Biracial Children, 92 MicH. L. REV. 925 (1994) (noting that black and biracial children raised by white parents generally do well).

125. Eleana J. Kim, Adopted Territory: Transnational Korean Adoptees and the Politics of Belonging (2010); Susan Soon-Keum Cox, Ritual, 9 Yale J.L. \& Feminism 17 (1997).

126. Susan R. Harris, Race, Search, and My Baby-Self: Reflections of a Transracial Adoptee, 9 Yale J.L. \& Feminism 5, 5-10 (1997). See generally, Ruth G. McRoy, Zena Oglesby \& Helen Grape, Achieving Same-Race Adoptive Placements for African American Children: Culturally Sensitive Practice Approaches, in SERVING AFRICAN AMERICAN CHILDREN (Sondra Jackson \& Sheryl Brisset-Chapman eds., 1999).

127. See supra note 108 .

128. See supra notes $107-108$ and accompanying text. 


\section{INTERCOUNTRY HUMAN RIGHTS FOR THE NEW GILDED AGE}

David Harvey argues that the real goal of neoliberalism was to restore wealth to the top one percent of the population. ${ }^{129}$ In the developed global North, social safety nets have been slashed. Environmental regulations, along with health and laborsafety regulations, have been rescinded, or are not enforced. Once-public services, from education to neighborhood security, have been privatized. In the "developing" global South - the site of most manufacturing that still requires humans rather than robots - there were few social safety nets to slash, or regulations for businesses to worry about.

While the world is wealthier than ever before, global poverty has in fact increased. This Part explains this apparent paradox by showing how the Great Recession led to unprecedented inequality. ${ }^{130}$ It then explains why intercountry adoption requires intercountry human rights. It concludes by suggesting how intercountry human rights might operate in practice.

\section{A. The New Gilded Age}

\section{The Global Recession}

Neoliberalism promised that globalization and capitalism would improve human well-being where badly managed, often corrupt, social welfare schemes had failed. This seemed plausible to many before the Great Recession of 2008. ${ }^{131}$ In 2007, the subprime mortgage market collapsed in the United States. The housing bubble burst and markets panicked, triggering a global recession. ${ }^{132}$

The United States economy constituted such a large proportion of the global economy that when it sank, it took the rest of the world with it. ${ }^{133}$ In addition, the United States exported its recession because it had already exported its neoliberal philosophy of deregulation, privatization, and slashed social safety nets. ${ }^{134}$ The Great Recession spread like wildfire because neoliberal globalization had already eliminated the barriers that might have slowed it.

129. HARVEY, supra note 91, at 15-18 (drawing on the analyses of data by Gérard Duménil and Dominique Lévy, charting the "extraordinary concentrations of wealth and power emerging all over the place").

130. See generally Barbara Stark, How the Age of Rights Became the New Gilded Age: From International Antidiscrimination Law to Global Inequality, 47 Colum. Hum. RTs. L. REV. 151, 177-86 (2015).

131. Joseph E. Stiglitz, Making Globalization Work 68 (2006).

132. Joseph E. Stiglitz, Freefall: America, Free Markets, and the Sinking of the World ECONOMY 21-24 (2010) [hereinafter Stiglitz, FreEfall]. Twenty-five percent of U.S. mortgages were held by foreign banks. Id. at 21 .

133. Id.

134. See, e.g., Joseph M. Schwartz, Democracy Against the Free Market: The Enron Crisis and the Politics of Global Deregulation, 35 ConN. L. REV. 1097 (2003); see also Stark, supra note 130 , at $178-79$. 
Those in low income states were especially vulnerable. ${ }^{135}$ They were immediately hit by the collapse in global demand. Remittances - which have always dwarfed foreign aid - from the United States and Europe fell. ${ }^{136}$ The crises hit especially hard because social safety nets were already weakened by structural adjustment programs (SAPs) foisted on developing states by the IMF and by 'austerity' adopted in the European Union and foisted on struggling states like Greece and Italy. ${ }^{137}$

\section{Unprecedented Inequality}

Ten years ago, the World Bank reported a broad reduction in extreme poverty. ${ }^{138}$ While there was a drop in the number of people living below one dollar per day, "[t]he number of people living between $\$ 1.25$ and $\$ 2$ has almost doubled from 648 million to 1.18 billion between 1981 and 2008." ${ }^{139}$ As the World Bank put it, there are "More Relatively-Poor People in a Less Absolutely-Poor World." 140 As Thomas Piketty has shown, birth predicts wealth as certainly as it did during the Gilded Age. ${ }^{141}$

While there has been an increase in total global wealth, global inequality grew until 2015 , when the top $1 \%$ owned $47.5 \%$ of it. ${ }^{142}$ If, as Friedman predicted and the Washington Consensus promised, neoliberalism was intended to benefit everyone, it

135. Stiglitz, Freefall, supra note 132, at 23; see also Mark Weisbrot, Globalization for Whom?, 31 CORNELL INT'L L.J. 631, 632 (1998) ("The Asian economic crisis also threw a wrench into the machinery of financial liberalization. The crisis opened a whole new debate over how to protect national economies from the instability caused by international capital flows. Even more importantly, the crisis has caused people to question the role of globalizing institutions, such as the International Monetary Fund (IMF), in dealing with international economic problems.").

136. StiglitZ, FreEFALl, supra note 132, at 24. Remittances were further reduced because the money transfer companies that enabled families to send money to keep their children in school were often the same companies that were used to send money to terrorist groups, such as the Shabab in Somalia. Nicholas Kulish, Somalis Face a Snag in Lifelines from Abroad, N.Y. Times (Aug. 4, 2013), https://www.nytimes.com/2013/08/04/world/africa/somalis-face -snag-in-lifeline-from-relatives-working-abroad.html [https://perma.cc/8V8P-GP5N].

137. Stiglitz, Freefall, supra note 132, at 24.

138. Annie Lowrey, Dire Poverty Falls Despite Global Slump, Report Finds, N.Y. TIMES (Mar. 6, 2012), https://www.nytimes.com/2012/03/07/world/extreme-poverty-down-despite -recession-world-bank-data-show.html [https://perma.cc/5XWZ-44AJ].

139. Shaohua Chen \& Martin Ravallion, An Update to the World Bank's Estimates of Consumption Poverty in the Developing World 3 (Mar. 1, 2012), http://siteresources.worldbank.org/INTPOVCALNET/Resources/Global_Poverty_Update_2 012_02-29-12.pdf [https://perma.cc/F6XC-KCBF]. As the Bank notes, moreover, "[1]ags in data availability mean that 2008 is the most recent year we can make a reliable global estimate ...." Id. at 1 .

140. Shaohua Chen \& Martin Ravallion, More Relatively-Poor People in a Less Absolutely-Poor World (The World Bank Dev. Research Grp., Policy Research Working Paper No. 6114, 2012).

141. Thomas Piketty, Capital in the Twenty-First Century 408-09, 421 (Arthur Goldhammer trans., 2014).

142. Anthony Shorrocks, James Davies \& Rodrigo Lluberas, Credit Suisse, Global WeALth RePORT 2018, at 9 (2018). 
has been a spectacular failure. As Christine Lagarde, the Managing Director of the International Monetary Fund (IMF), has noted, "There has been a staggering rise in inequality -7 out of 10 people in the world today live in countries where inequality has increased over the last three decades. And yet, we know that excessive inequality saps growth, inhibits inclusion, and undermines trust and social capital."143

Children - everywhere - are disproportionately poor. ${ }^{144}$ Children make up nearly half of the almost 900 million people living on less than $\$ 1.90$ day; ten million of the twenty-one million people who have been forcibly displaced from their homes are children. ${ }^{145}$ Fifty-eight million children, between six- and eleven-years-old, are out of school. ${ }^{146}$ Most of them are girls. ${ }^{147}$

Neoliberalism is not going to help them. Growth so robust that everyone will enjoy its benefits is a fantasy. In fact, trade is no longer rising. ${ }^{148}$ Even in the United States, those on the bottom half of the income ladder "ha[ve] been completely shut off from economic growth since the 1970s." ${ }^{149}$ Families, trying to keep up with capital that crosses continents at the stroke of a key, are already dispersed. Social safety nets have already been slashed.

The Trump administration has recently added to the global pain. Since Ronald Reagan announced the Mexico City Policy, also known as the Gag Rule, in 1981, Republican presidents have barred the United States from funding any foreign NGO

143. Christine Lagarde, Managing Dir., Int'l Monetary Fund, Address at the Joint IMF/World Bank Annual Meeting: The IMF at 70: Making the Right Choices-Yesterday, Today, and Tomorrow 3 (Oct. 10, 2014).

144. UNICEF, The State of THE World's Children 2016: A FAIR ChanCE FOR Every CHILD 72 (2016).

145. Id.

146. UNeSco institute for Statistics, Fixing the Broken Promise of Education FOR All: Findings From the Global Initiative ON OUt-OF-SCHOOl CHILdREN 23 (2015). 147. Id.

148. See, e.g., Binyamin Appelbaum, A Little-Noticed Fact About Trade: It's No Longer Rising, N.Y. Times: TheUpshot (Oct. 30, 2016) https://www.nytimes.com/2016/10/31/upshot /a-little-noticed-fact-about-trade-its-no-longer-rising.html [https://perma.cc/TTV5-8Q4Y] ("The volume of global trade was flat in the first quarter of 2016 , then fell by 0.8 percent in the second quarter .... Through the first nine months of 2016, trade fell by an additional $\$ 470$ billion."); Peter S. Goodman \& James Kanter, With Europe-Canada Deal Near Collapse, Globalization's Latest Chapter Is History, N.Y. TIMES (Oct. 21, 2016), https://www.nytimes .com/2016/10/22/business/international/european-union-canada-trade-agreement-ceta.html [https://perma.cc/3PAZ-QMSX] ("Liberalized trade has amplified economic growth, but the spoils have been largely monopolized by wealthy and corporate interests. Recriminations over the resulting economic inequalities are now so ferocious that modern history has been altered: the phase of globalization that began with the ending of World War II is essentially over.").

149. Patricia Cohen, A Bigger Economic Pie, but a Smaller Slice for Half of the U.S., N.Y. TiMES (Dec. 6, 2016), https://www.nytimes.com/2016/12/06/business/economy/a-biggereconomic-pie-but-a-smaller-slice-for-half-of-the-us.html [https://perma.cc/BZZ2-ZYJK] (citing findings by economists Thomas Piketty, Emmanuel Saez, and Gabriel Zucman showing that despite small increases in public programs, inequality has soared - the income of the lower half remains roughly $\$ 16,000$; the top $1 \%$ averages $\$ 1,304,800$, eighty-one times as much). 
that even counsels women regarding abortion as part of family planning services. ${ }^{150}$ Democratic presidents have consistently stricken the Gag Rule upon taking office, restoring roughly $\$ 575$ million to international family planning programs. Trump has extended the Gag Rule to include $\$ 8.8$ billion in funding from the State Department, United States Agency for International Development (USAID), and the Department of Defense. ${ }^{151}$ This includes cutting the United States' annual contribution to the UN Population Fund, which promotes family planning. This unprecedented withdrawal of support leaves millions of women without reproductive health care. A surge in unplanned and unwanted births is likely. ${ }^{152}$ In February 2019, the Department of Health and Human Services announced new rules regarding Title X, which would effectively impose a gag rule on family planning services in the United States that receive federal funds..$^{153}$

150. See Luisa Blanchfield, Cong. Research Serv., R41360, Abortion and Family Planning-Related Provision in U.S. Foreign Assistance Law and Policy 10-11 (2019). The Helms Amendment to the Foreign Assistance Act of 1973 already bans the use of United States foreign aid for abortions. Id. at 3 .

151. See Memorandum on the Mexico City Policy, 2017 Daily Comp. Pres. Doc. 63 (Jan. 23, 2017); Laura Bassett, Donald Trump Drastically Expands 'Global Gag Rule' on Abortion, HuFFingTON POst (May 16, 2017, 4:09 AM), http://www.huffingtonpost.com.au/2017/05/15/ donald-trump-drastically-expands-global-gag-rule-on-abortion_a_22092544/?utm_hp_ref=a u-sexual-health [https://perma.cc/3YPV-PEMD]; see also Ann M. Starrs, The Trump Global Gag Rule: An Attack on US Family Planning and Global Health Aid, 389 LANCET 485 (2017). Starrs, President of the Guttmacher Institute, anticipates an even broader impact. As she explains, “[u]nder Trump's order, the gag rule now applies not only to US bilateral family planning assistance (US\$575 million for fiscal year 2016), but also to all 'global health assistance furnished by all departments or agencies' - encompassing an estimated $\$ 9.5$ billion in foreign aid." $I d$. (footnotes omitted).

152. The burden on already stressed intercountry adoption networks is unlikely to be the only effect. As Eugene Linden, author of THE Alms RACE (1976), observed, "the [p]opulation [b]omb [is] [s]till [t]icking." Eugene Linden, Remember the Population Bomb? It's Still Ticking, N.Y. TIMES (June 15, 2017), https://www.nytimes.com/2017/06/15/opinion /sunday/remember-the-population-bomb-its-still-ticking.html [https://perma.cc/3B88-VUF6]. The "population bomb" has been used since the 1970s to refer to the risks posed by unchecked population growth, given the finite resources of the planet. The Green Revolution and globalization may have postponed the reckoning, Linden argues, but the risks are even greater now, in view of the current population figures (approximately 7.6 billion) and the impact of climate change.

153. See Press Release, U.S. Dep't Health \& Human Servs., HHS Releases Final Title X Rule Detailing Family Planning Grant Program (Feb. 22, 2019), https://www.hhs.gov/about /news/2019/02/22/hhs-releases-final-title-x-rule-detailing-family-planning-grant-program .html [https://perma.cc/R5MX-VQ6T] (requiring clear separation between Title X funded projects and programs where "abortion is a method of family planning"); see also Editorial Board, Opinion, Birth Control Gets Caught Up in the Abortion Wars, N.Y. TimEs (Feb. 26, 2019), https://www.nytimes.com/2019/02/26/opinion/title-x-rule.html [https://perma.cc /YMH6-X64B]. On March 4, 2019, California filed a lawsuit to block the move, and "20 other states, along with Washington, D.C., said that they would file a separate lawsuit challenging the same restrictions." Jose A. Del Real \& Robert Pear, California Sues Trump Administration to Block Restrictions to Family Planning Program, N.Y. Times (Mar. 4, 2019), 


\section{B. Why Intercountry Adoption Requires Intercountry Human Rights}

\section{Why the Hague Convention Is Not Enough}

Adoption law is governed by national law, and different national laws are coordinated by the Hague Convention on Intercountry Adoption. ${ }^{154}$ But the Hague Convention is only binding when both the state of origin and the receiving state are parties. Even if both states are parties, moreover, the Hague Convention provides minimal human rights protection. Like many domestic adoption laws, the Convention protects the rights of biological families and protects adoptive parents from subsequent claims, by requiring the voluntary surrender of the child by the biological parents. ${ }^{155}$ But the Hague Convention does not purport to subject the adoption to human rights law.

Intercountry adoption advocates agree that the child must be "properly" separated from both biological parents. ${ }^{156}$ This means that children cannot be sold or abducted and parents cannot be deceived. They cannot be told, for example, that their children will come back to them or send for them in the future. ${ }^{157}$ But the Hague Convention does not require consideration of the violations of the parents' human rights that may have led to the surrender of the child. When babies were abandoned by Chinese parents subject to the one-child policy, for example, the obvious coercion did not preclude Hague adoptions. ${ }^{158}$

\section{Human Rights Issues Raised by Adoption}

The human rights issues that arise most frequently in the context of intercountry adoption - gender, racial, or other forms of discrimination and the denial of economic rights - are well known in both states of origin and receiving states. The prohibition against racial discrimination is a jus cogens norm, from which no derogation is permitted. ${ }^{159}$ Economic rights and the prohibition against gender discrimination, if less well entrenched, are not only included in the International Bill

https://www.nytimes.com/2019/03/04/us/california-lawsuit-title-x-family-planning.html [https://perma.cc/E57K-CJR3].

154. Convention on Protection of Children and Cooperation in Respect of Intercountry Adoption, supra note 13.

155. See id. at art. 4(c).

156. See id.

157. See Blair, supra note 114 , at $365-74$.

158. China became a party to the Hague Convention in 2005, and it entered into force in China in 2006. The one-child policy officially ended on January 1, 2016. Feng Wang, Baochang Gu \& Yong Cai, The End of China's One-Child Policy, Brookings (Mar. 30, 2016), https://www.brookings.edu/articles/the-end-of-chinas-one-child-policy/ [https://perma .cc/YQ5V-UBF6].

159. Antonio Cassese, A Plea for Global Community Grounded in a Core of Human Rights, in ReAlizing Utopia: The Future of International Law 137, 139 (2012), reprinted in Philip Alston \& Ryan Goodman, International Human Rights 163 (2013). 
of Rights but in a growing number of national constitutions. ${ }^{160}$ Neither is addressed in the Hague Convention, beyond the prohibition against baby selling.

Intercountry adoption raises human rights issues not only at the time of the adoption but over the life span of the adoptee, as well as over the life spans of both her biological and her legal parents. These rights, too, are missing from the Hague Convention.

\section{a. Economic, Social, and Cultural Rights}

The economic rights set out in the Economic Covenant matter in intercountry adoption because parents who lack these rights, including the reproductive rights that are part of the Article 12 right to health, ${ }^{161}$ may be forced to abandon or surrender children they never wanted or cannot support. Without an education ${ }^{162}$ and work, ${ }^{163}$ mothers and fathers can't provide for their families. Without an adequate standard of living including food, shelter, and clothing for themselves and their children, ${ }^{164}$ parents, especially single mothers, are forced to make desperate choices like "surrendering" a child for adoption in order to feed her siblings.

Article 10 directly impacts intercountry adoption. It provides in pertinent part that, "[t]he widest possible protection and assistance should be accorded to the family . . . particularly for its establishment and while it is responsible for the care and education of dependent children." 165 State support for young families, when they are having their first or second child, would probably enable more families to keep their children, rather than be forced to give them up for adoption. Article 10.2 requires states to assure "[s]pecial protection ... to mothers during a reasonable period before and after childbirth. During such period working mothers should be accorded paid leave or leave with adequate social security benefits." ${ }^{166}$ Article 10.3 addresses the rights of children, requiring the state to assure "[s]pecial measures of protection and assistance ... on behalf of all children ... without any discrimination for reasons of parentage ... . Children . . . should be protected from economic and social exploitation." 167 Article 12 requires the state to safeguard "the right of everyone to the enjoyment of the highest attainable standard of physical and mental health."168 Article 12.2(a) specifically requires states to reduce stillbirth and infant mortality

160. David S. Law \& Mila Versteeg, The Declining Influence of the United States Constitution, 87 N.Y.U. L. REV. 762, 833-40 (2012) (noting that the United States Constitution is no longer the most popular model because it omits economic rights and does not prohibit gender discrimination).

161. Economic Covenant, supra note 1, at art. 12; see also Human Rights and Health, WORLD HeAlth ORG. (Dec. 29, 2017), http://www.who.int/mediacentre/factsheets/fs323/en/ [https://perma.cc/FHL2-2R73].

162. Economic Covenant, supra note 1, at arts. 13-14.

163. See id. at arts. 7-8.

164. Id. at art. 11.

165. Id. at art. 10.1 .

166. Id. at art. 10.2.

167. Id. at art.10.3.

168. Id. at art. 12.1 . 
rates and to provide for the "healthy development of the child." ${ }^{169}$ Both articles are violated when intercountry adoption is promoted in places where people are desperate, and safeguards are few. ${ }^{170}$

\section{b. Nondiscrimination}

The right against nondiscrimination is violated when babies are surrendered for adoption on the basis of gender, race, or ethnicity. Gender discrimination in adoptions takes many forms. Parents abandoned baby girls in China when the onechild policy was in effect, for example, hoping that their "one-child" would be a boy. ${ }^{171}$ The parents' discriminatory preference was perpetuated, rather than addressed, by state support of intercountry adoption. Many of the adoptive families, in contrast, preferred girls, so it could be argued that for the adoptees, at least, the discrimination was mitigated. ${ }^{172}$

When the Sudanese girls fleeing civil war were "adopted" by families in the refugee camp in Kenya, on the other hand, the adoptees were subject to a different form of gender discrimination. ${ }^{173}$ As the UN High Commissioner for Refugees reported, the girls were taken into foster families, but their role was frequently that of "unpaid servants." 174 They cooked, cleaned, and gathered firewood for their foster families. That was not their only value, nor the only reason they were taken in.

169. Id. at art. 12.2(a).

170. See Blair, supra note 114 , at 355-65.

171. See Barbara Stark, Baby Girls from China in New York: A Thrice-Told Tale, 2003 UTAH L. REV. 1231, 1242 (2003).

172. It has been estimated, however, that a very small proportion-less than $1 \%$ of the "missing baby girls" (girls predicted to be born statistically) —were adopted by foreign parents, $90 \%$ of whom are from the United States. By 1995, China was the main source of infant orphans coming to the United States. See id. at 1256 (explaining why American parents adopt internationally). In the same year, Human Rights Watch published Death by Default, a report on the appalling conditions in Chinese orphanages, including "dying rooms" where unwanted babies were allowed to starve to death. See Human Rights Watch, Death by Default: A Policy of Fatal Neglect in China's State Orphanages (Robin Munro \& Jeff Rigsby eds., 1996), https://www.hrw.org/legacy/summaries/s.china961.html\#TOC [https://perma.cc/D7EG-9U2T] (“[O]verall annual mortality at many of China's orphanages is far higher than that documented in any other country."). Death by Default found that most abandoned children died within a year of their admittance to a state-run orphanage. Orphanages were quickly closed to foreign visitors. See id. In 1996, the Ministry of Civil Affairs assumed responsibility for adoptions. See id.

173. See Barbara Stark, Lost Boys and Forgotten Girls: Intercountry Adoption, Human Rights, and African Children, 22 St. Louis U. PuB. L. Rev. 275, 277-81 (2003).

174. Emmanuel Nyabera, Man-Eating Lions, Crocodiles, Famine..., 1 RefugeEs 8, 8-9 (2002) ("Following Sudanese cultural traditions, many of the girls were absorbed into foster homes and left to a very uncertain fate, overlooked and forgotten by the outside world."); see also Ishbel Matheson, The 'Lost Girls' of Sudan, BBC NEWS (June 7, 2002, 3:57 PM), http://news.bbc.co.uk/2/hi/africa/2031286.stm [https://perma.cc/U2C7-TADS] (describing the chores of seventeen-year-old Grace Anyieth, "cooking, cleaning, washing, fetching water from the distant stand-pipe, looking after her guardian's children. In other words, she is an unpaid servant."). 
Families expect a bride price for a "daughter," and several of the girls were given by their foster families in arranged marriages, ${ }^{175}$ in violation of the African Charter and CEDAW. ${ }^{176}$

Racial discrimination in intercountry adoption is similarly complicated. A child whose surrender may have been triggered by bias against a half-white child in her country of origin, for example, may find herself discriminated against in a white American suburb because she is half Asian. ${ }^{177}$ While it can be argued that a child is always better off with parents who want her, rather than with parents who don't, parents' desire for a child does not mean that they can cope with racism, or even recognize it. ${ }^{178}$ Finally, cultures change and racism - and the experience of racismchanges as the adoptee grows up.

As the adoptee matures, other human rights may become important to her, including the rights to know her birth parents and her culture, to be part of a community, and to be part of a country. ${ }^{179}$ The child's "right to belong" has social, psychological, and political consequences. ${ }^{180}$ Again, these rights are not addressed in the Hague Convention.

\section{Intercountry Human Rights}

Intercountry human rights would effectively merge the state of origin and the receiving state into a single functioning unit for purposes of assuring the human rights involved in intercountry adoption. The legal mechanism for accomplishing this could be a simple protocol to the Hague Convention, modeled after the African Charter on the Rights and Welfare of the Child. ${ }^{181}$ Under the African Charter, intercountry adoption is limited to those countries that are either parties to the Charter or to the CRC. ${ }^{182}$ Under this proposal, similarly, the protocol would limit intercountry

175. See Matheson, supra note 174 ("Although an estimated 3,000 [girls] arrived in Kakuma in 1992, most have simply vanished from official records. . . According to Sudanese custom, the girls were placed with guardians who were supposed to protect them. But many foster parents - it seems - did not have the girls' welfare at heart. In a place where poverty is rampant, young women are a valuable commodity. They can be sold off for a good brideprice.").

176. CEDAW, supra note 8 , at 6-7 (prohibiting arranged and child marriages in article 16).

177. See supra note 118 .

178. See supra notes 127-28.

179. See CRC, supra note 8, at 3, 6 (articles 7 and 21).

180. There is growing literature on this subject, ranging from personal accounts to nascent movements, including initiatives by Korean adoptees to find birth parents and reclaim their culture. See, e.g., Kim, supra note 125; Marie Tae McDermott, Adopted Koreans, Stymied in Search of Birth Parents, Find Hope in a Cotton Swab, N.Y. Times (Aug. 27, 2016), https:/www.nytimes.com/2016/08/28/world/asia/south-korea-adoptees-325kamra.html [https://perma.cc/6CPW-ZC27] (explaining how "DNA testing offers a way around the bureaucratic hurdles and flawed records").

181. Organization of African Unity, African Charter on the Rights and Welfare of the Child, July 11, 1990, OAU CAB/LEG/153/Rev. 2 (entered into force Nov. 29, 1999).

182. Id. at 18 (article 24(b)). States such as the United States, which has not ratified three out of four of the applicable human rights instruments, would not be eligible to ratify the 
adoption to states that are parties to the protocol. The protocol would grant jurisdiction to each state over the relevant parties of the other state, including state agencies directly involved in intercountry adoption, for purposes of assuring the human rights of those affected by the proposed adoption.

This Section first sets out the theory in which this proposal is grounded. This theory builds on a fundamental premise of human rights law (the recognition of the individual as a subject of international law). Second, it draws on Thomas Paine's theory of state obligation, set out in Agrarian Justice. ${ }^{183}$ Third, it can be understood as part of the ongoing fragmentation of international law. Finally, it reflects and incorporates the growing resistance to neoliberalism.

This Section then sketches how the proposal might function in this context. It would enable individuals to expose human rights violations. It might help some parents keep their children, if that is what they want, or place them with another family while maintaining some contact, if that is their choice. More ambitiously, it would make the traditionally rigid boundaries of state sovereignty marginally more porous for human rights.

\section{In Theory}

There is no need for any theoretical justification for the mechanism proposed here; it is simply a treaty between, or among, consenting states. There is no encroachment on state sovereignty. Why states should accede to such a treaty, and more broadly, embrace the notion of intercountry human rights, is less straightforward.

\section{a. The Individual's Right to Petition}

While this proposal stretches the paradigm of human rights as a matter exclusively between a state and its own people, this paradigm has been expanding since its inception. The proliferation of human rights treaty bodies and regional courts, and the vast networks of international organizations and NGOs, which work together to provide aid, healthcare, and technical assistance, suggest the scope of that expansion. ${ }^{184}$

Allowing individuals to have access to specialized courts or committees through optional protocols permitting a right of individual petition also expands the paradigm. All but one of the ten main human rights treaty bodies provide for the submission of individual petitions, although not all have entered into force. ${ }^{185}$ But the international system is bogged down. There are simply too many reports to be submitted and reviewed. Backlogs resulting in delays of up to seven years often make the process pointless. ${ }^{186}$

Protocol until it had. Islamic states that do not recognize formal legal adoption would also be excluded.

183. See Thomas Paine, Agrarian Justice: Opposed to Agrarian Law and to Agrarian Monopoly, in PAine: Collected Writings 396 (Eric Foner ed., 1995) (1797).

184. See, e.g., Alston \& GoOdMAn, supra note 159, 685-762 (giving an overview of the $\mathrm{UN}$ system, the treaty bodies, and regional arrangements).

185. Id. at 808 n.26.

186. See id. at 842 . 
Scaled down and adequately supported, however, the right of individual petition has been remarkably popular over time. The European Court of Human Rights, for example, established the right of individual petition in $1955 .{ }^{187}$ In 1998, Protocol No. 11 was adopted, making the right of petition mandatory. ${ }^{188}$ Between 2000 and 2009, the Court received more than 330,000 applications and issued more than 11,000 judgments. ${ }^{189}$

\section{b. The States' Obligation}

In Agrarian Justice, a short pamphlet written in 1795-96, the eighteenth-century American philosopher Thomas Paine explained why the state should be required to assure the necessities of life for all of its residents. ${ }^{190}$ In a state of nature, he explained, everyone was free to hunt, fish, and gather whatever wild edibles were available. ${ }^{191}$ This freedom was taken away by the state, however, when it established the law of private ownership of property. ${ }^{192}$ The state had an obligation, accordingly, to those who were effectively deprived of the ability to support themselves by these new laws of private property. ${ }^{193}$

While the situation may be more complex today, as described in Part II, the same basic principle should apply. It is not merely access to hunting, fishing, and wild edibles that has been taken away, however, but the ability to participate in a global economy, profits from which go mainly to investors. ${ }^{194}$ Providing individuals from states of origin with limited access to specialized courts and agencies in receiving states seems a modest recompense.

\section{c. The Fragmentation of International Law}

This proposal would be part of the ongoing fragmentation of international law; that is, the proliferation of often overlapping laws and fora to address a range of problems described in the Report of the International Law Commission on the Fragmentation of International Law ("ILC Report"). ${ }^{195}$ As Ingrid Wuerth noted in

187. Mark Weston Janis \& John E. Noyes, International Law: Cases and COMMENTARY 501 (5th ed., 2014).

188. Id. at 502 .

189. Id.

190. See PAINE, supra note 183.

191. Id. at 7-8.

192. Id. at 9 .

193. Id. at 10 .

194. See Jared Bernstein, Yes, Stocks Are Up. But 80 Percent of the Value Is Held by the Richest 10 Percent, WASH. POST (Mar. 2, 2017, 8:55 AM), https://www.washingtonpost.com /posteverything/wp/2017/03/02/perspective-on-the-stock-market-rally-80-of-stock-value-hel d-by-top-10/ [https://perma.cc/W7GU-SAT5] (noting that within the top 10\%, the share of stock wealth held by the top $1 \%$ is roughly equal to the share held by the $90-99$ th percentiles). While capital flows freely over state borders, moreover, humans must get permission to enter a country and to stay there. Even those who clearly qualify as refugees have no right to asylum in any particular place. They can only join the sixty-five million people waiting in refugee camps for states to decide where they might go.

195. See Rep. of the Study Group of the Int'1 Law Comm'n, Fragmentation of International 
connection with the Kiobel decision, "For all the downsides of fragmentation, the resulting tumult provides an opportunity for human rights activists to achieve in one forum what they could not in another." 196 This is an objective of the proposal here, that is, the protection of human rights in one forum - here, an American forum - that could not be achieved in the state of origin. The legal and administrative infrastructure taken for granted in many receiving states does not exist in many states of origin. Shutting down adoption programs that fall short of international standards does not necessarily mean that a state plans to meet those standards and to spend whatever may be needed to do so. An offer of assistance by a foreign agency, or a penalty imposed by a foreign forum, might be more effective.

The "arc of the ATS litigation," as Wuerth puts it, ${ }^{197}$ is instructive. She describes the early cases like Filartiga,${ }^{198}$ brought by human rights advocates who quickly realized the value of the American legal system to those from states lacking the most basic protections. In this context, too, the legal and administrative resources of the global North could be invaluable for human rights advocates seeking support for families in the global South. In the ATS context, moreover, the acts complained of had no relation to the state in which relief was sought. Intercountry adoption, in contrast, is driven by the economic gap between the developed global North and the still-struggling global South, a gap from which the global North still profits.

In Wuerth's account, ATS litigation was, in part, a victim of its own success, as cases shifted from individual defendants represented by public interest groups to corporate defendants such as Barclays, Chevron, Ford, and IBM, represented on both sides by major firms. ${ }^{199}$ The risk of such a trajectory is remote in the context of intercountry adoption, since the profits of multinational corporations are not at stake. $^{200}$

\section{d. Resisting Neoliberalism}

Finally, intercountry human rights can be understood as part of a growing resistance to neoliberalism. The objective here is to deprivatize intercountry adoption

Law: Difficulties Arising from the Diversification and Expansion of International Law, 58th Sess., May 1-June 9, Jul. 3-Aug. 11. 2006, U.N. Doc. A/CN4/L.682 (Apr. 13, 2006) (finalized by Martii Koskenniemi, Chairman).

196. Ingrid Wuerth, Kiobel v. Royal Dutch Petroleum Co.: The Supreme Court and the Alien Tort Statute, 107 Am. J. INT'L L. 601, 621 (2013). In Kiobel, the Supreme Court brought a halt to human rights litigation under the ATS. See, e.g., Anne-Marie Burley, The Alien Tort Statute and the Judiciary Act of 1789: A Badge of Honor, 83 Am. J. INT'L L. 461 (1989). See generally Barbara Stark, International Law from the Bottom Up: Fragmentation and Transformation, 34 U. PA. J. INT'L L. 687 (2013).

197. Wuerth, supra note 196, at 621.

198. Filartiga v. Peña-Irala, 630 F.2d 876 (2d Cir. 1980); see also Burley, supra note 196.

199. Wuerth, supra note 196, at 604.

200. Other trajectories, such as the development of supportive transnational networks and links, eventually, to a treaty body like those described in Gráinne de Búrca, Human Rights Experimentalism, 111 AM. J. INT'L L. 277 (2017), seem more plausible. See generally THOMAS Risse, Stephen C. Roop \& Kathryn Sikkink, The Power of Human Rights (2009) (describing a "spiral" model of human rights development and its evolution during the first decade of the twenty-first century). 
and establish or reinstate more effective social safety nets, along with sensible regulations that better protect poor or otherwise marginalized parents and children.

The value of human rights law here is its insistence on placing human needs before those of markets. Intercountry human rights recognize the bland, technical imperatives of neoliberalism-deregulation, slashed social safety nets, and privatization - as direct and deadly violations of human rights. ${ }^{201}$ Slashed social safety nets contribute to grim outcomes regarding life expectancy and mortality. ${ }^{202}$ "Privatization" means that the cost of any "public" service must include an increment for the private providers' profit, even as those providers remain insulated from accountability. Privatization directly - and often dramatically — contributes to the sinking quality of life for those at the bottom.

\section{In Practice}

Intercountry human rights would enable individuals, or NGOs acting on behalf of individuals, to seek enforcement of human rights through the courts or appropriate agencies of partnering states. The shared commitment of the participating states to the relevant human rights, including the child's "right to know and be cared for by his or her parents," ${ }^{203}$ would establish the legal parameters of a claim. ${ }^{204}$ Only "if the child cannot be placed in a foster or an adoptive family or cannot in any suitable manner be cared for in the child's country of origin" is intercountry adoption to be considered under Article 21(b) of the CRC. ${ }^{205}$ The precise mechanisms applicable in a particular case would depend upon the mechanisms already available to nationals, the relationship between the states, their physical proximity, and the particular human rights at stake.

201. Deregulation in London, which left fire safety to individual building managers, for example, led to the Grenfell Tower fire, in which more than seventy-nine people died. Steven Erlanger, After Grenfell Tower Fire, U.K. Asks: Has Deregulation Gone Too Far?, N.Y. TimES (June 28, 2017), https:/www.nytimes.com/2017/06/28/world/europe/uk-grenfell-tower-firederegulation.html [https://perma.cc/T7AY-N8EJ]; Megan Specia, Would This London HighRise Past Muster in New York? Short Answer: No, N.Y. Times (June 27, 2017), https://www.nytimes.com/2017/06/27/world/europe/london-high-rise-fire-new-york-regulat ion.html [https://perma.cc/F842-F7EV]. Deregulation is often linked to privatization. "Deregulation also meant outsourcing responsibility for fire inspections to owners and builders, instead of civil servants." Erlanger, supra.

202. For example, life expectancy in northern China has fallen by five years because of air pollution. Yuyu Chen, Avraham Ebenstein, Michael Greenstone \& Hongbin Li, Evidence on the Impact of Sustained Exposure to Air Pollution on Life Expectance from China's Huai River Policy, 110 Proc. NAT'L ACAD. Sci. U.S. 12936 (2013).

203. CRC, supra note 8 , at art. 7.

204. Only if the right to know her parents is not possible, or contrary to the child's best interest, should a child be "ensure[d] alternative care." Id. at art. 20.2.

205. Id. at art. 21(b). 


\section{a. The Individual's Right to Petition}

The right of individual petition before a court or the appropriate agency of the partnering state could be especially useful in this context, since the optional protocols for individual communications have not yet come into effect for the Economic Covenant or the CRC. ${ }^{206}$ Even if they do come into force, or even if a particular case gives rise to a claim under the Civil Covenant's optional protocol, ${ }^{207}$ an NGO representing children or parents may well prefer a more specialized and focused alternative, especially in view of the long delays associated with international procedures. While states may be reluctant to accept a comprehensive right of individual petition before an international body, moreover, a presumably simpler, faster, much more limited right (applying only in the context of intercountry adoption) might be more palatable, especially if it was linked to material support.

\section{b. The States' Obligation}

As Professor Smolin notes, in China and Korea, abandonment or surrender of a child is not usually caused by extreme poverty. ${ }^{208}$ In other states of origin, however, intercountry adoptions are often grounded in poverty. As Smolin argues:

[I]ntercountry adoptions based on poverty [are] cruel and unethical, compounding the vulnerability and suffering of the poor with the loss of their children, and absurdly spending tens of thousands of dollars for an intercountry adoption when perhaps one hundred dollars or less would have been sufficient to maintain the child with her family. ${ }^{209}$

The human rights of the parents, as well as the child, are violated when parents are forced to surrender babies because they cannot afford to take care of them.

As economist Andy Sumner has shown, most of the poorest people in the world live in middle-income countries, which are presumably able to assure the basic needs of their nationals. ${ }^{210}$ It is not clear whether the parents who surrender their children for adoption are in this group. If they are, the proposal here could help them hold their states accountable. According to the World Bank, moreover, all of the states of

206. Alston \& GoOdMAn, supra note 159 , at 840 .

207. See Civil Covenant, supra note 1, at 302 . The optional protocol to which I refer is the First Optional Protocol permitting individuals to file communications with the Human Rights Committee.

208. David M. Smolin, Child Laundering: How the Intercountry Adoption System Legitimizes and Incentivizes the Practices of Buying, Trafficking, Kidnapping, and Stealing Children, 52 WAYNE L. REV. 113, 127-28 (2006).

209. Smolin, supra note 7, at 1072.

210. Andy Sumner, Global Poverty and the New "Bottom Billion" Revisited: Exploring the Paradox that Most of the World's Extreme Poor No Longer Live in the World's Poorest Countries 3 (May 14, 2012) (working paper), https://www.ids.ac.uk/files/dmfile/Andy SumnerGlobalPoverty14May2012.pdf [https://perma.cc/6NL9-W9JT]. 
origin provide some form of paid parental leave. ${ }^{211}$ They are also parties to the Economic Covenant and are bound by Articles 10 and 12.212

Channeling subsidies or other forms of aid from one state to the other might also be an option. Again, this is hardly a radical proposition. Interstate aid is often used as a carrot to promote human rights. ${ }^{213}$ It has also been commonplace for nationals in receiving states to provide substantial "gifts" to agencies in states of origin. As Professor Bartholet argues, intercountry adoption increases awareness of the problems facing children in sending countries, exposing adoptive families and their communities to the plight of the children left behind. ${ }^{214}$ Some programs made support part of the process, like the Chinese orphanages that required parents to make $\$ 3000$ "donations" before they could leave with a child. Nor, she insists, do intercountry adoptions relieve the pressure on sending countries to address them. ${ }^{215}$ On the contrary, she asserts, it highlights them. Indeed, this is often touted as one of the benefits of intercountry adoption. ${ }^{216}$

But Bartholet conflates aid that perpetuates intercountry adoption with aid that might prevent it. An intercountry human rights approach, in addition to taking the human rights of all the parties into account, would also favor approaches that enable more parents to keep their children. ${ }^{217}$ Individual donations by adopting parents should be prohibited because they privilege the wealthy and commodify the relationship between the parents and the agency. Such payments may be especially problematic where human rights violations are ongoing, as in China during the era of the one-child policy. ${ }^{218}$

\section{CONCLUSION: TOWARD INTERCOUNTRY HUMAN RIGHTS}

This Article proposes a new, albeit modest, mechanism to support human rights, specifically those at risk in intercountry adoption. It has explained how the American version of human rights pushed aside a larger vision of human well-being and how it promoted privatized "solutions," such as intercountry adoption, instead. It has argued that those who have benefitted from neoliberalism owe something to those who have been penalized by it, just as Thomas Paine argued that the eighteenthcentury state owed something to those it effectively deprived of a livelihood. It has

211. See OECD Family Database, OECD, www.oecd.org/els/family/database.htm.

212. See supra Section III.B.2.

213. Alston \& GoOdman, supra note 159, at 1117-22.

214. Elizabeth Bartholet \& David Smolin, The Debate, in InTERCountry Adoption: Policies, Practices And Outcomes 233, 234-35 (Judith L. Gibbons \& Karen Smith Rotabi eds. 2012).

215. Id.

216. Id.

217. Like the Hague Convention, this approach would not necessarily favor all forms of in-country care, including group homes and orphanages, over intercountry adoption. Most children's advocates consider the quality of in-country care available, as well as the age and circumstances of the particular child. See, e.g., BLAIR ET AL., supra note 5, at 834-46.

218. This may be difficult to assess. See supra note 172 (describing the limited impact of adoption as well as the often-grim alternatives in China); supra note 122 (describing problems with adoptions and group homes in Guatemala). 
sketched how intercountry human rights might work in the context of intercountry adoption. Finally, this Article has suggested how intercountry human rights can be used to resist the domination of markets and the unprecedented concentration of global wealth which is its result. 